\title{
EFFECT OF BRUCELLA MELITENSIS ON THE SERUM LIPIDS PROFILES IN EWES
}

\author{
AL-NAQSHABENDY, A.A.; AVEEN A. IBRAHIEM ${ }^{* *}$ and AZEEZ, O.H. ${ }^{* * *}$ \\ *Department of Internal Medicine and Surgery, Faculty of Veterinary Medicine-University of Duhok-IRAQ. \\ ** Department of Chemistry, Faculty of Science, University of Zakho-IRAQ. \\ *** Department of Microbiology and Pathology, Faculty of Veterinary Medicine-University of Duhok-IRAQ.
}

Email: asselvet2000@yahoo.com

\section{ABSTRACT}

Received at: 3/6/2014

Accepted: 23/8/2014
The present study aimed to determine the seroprevalence of brucellosis in the serum of non vaccinated ewes by indirect enzyme-linked immunosorbent assay (I-ELISA), and to investigate possible effect of brucellosis on the serum lipids profiles in infected ewes and find correlation coefficients among all parameters. These study included examination of 120 blood serum samples (collected from non-vaccinated ewes) in different areas of Duhok Governorate, Iraq. Results showed that prevalence of brucellosis(by using I-ELISA) was $39.1 \%$ and also showed significant increased in total cholesterol, triglyceride (TG), in the investigated ewes (one week post abation) low density lipoprotein and high density lipoprotein levels, whereas very low density lipoprotein value is significantly decreased compared with the (negative for I-ELISA)group.

Key words: Brucella melitensis infection, lipid profiles, ewes.

\section{INTRODUCTION}

Brucellosis is an important re-emerging zoonosis with a worldwide distribution. Brucella infection is contagious for humans and the disease, unless diagnosed and treated both promptly and effectively, will become chronic, affecting multiple body systems (Young, 1995). Human infection usually occurred following ingestion of contaminated dairy foods and from occupational exposure to infected live animals or carcasses during slaughter. While, sheep and goats are the major reservoirs of B.melitensis infection, there is increasing evidence of emergence in cattle and camels (Young, 1995).

Lipids are essential for energy utilization, lipid deposition, steroid hormone production, and bile acid formation. The lipoprotein consists of esterified and unesterified cholesterol, triglycerides, phospholipids and protein. There are many major lipoproteins in blood including very low density lipoprotein (VLDL), intermediate density lipoprotein (IDL), low density lipoprotein (LDL) and high density lipoprotein (HDL). Each of these classes of lipoproteins carriers cholesterol and triglyceride to a varying degree, with LDL carrying the majority of cholesterol, and VLDL carrying the majority of triglyceride (Gagan, 2014).

In general, infected animal care issues related to screening and diagnosis are based on the results of the measurement of serum lipids, which is generally accomplished by obtaining a lipid profile. On occasion, measurement of serum lipoprotein is necessary for one or more of these purposes (Amal, 2009).

The aims of our study are to determine seroprevalence of brucella infection in the serum of non-vaccinated aborted ewes by indirect enzymelinked immunosorbent assay (I-ELISA), and to investigate possible effect of brucella infection on the serum lipids profiles in infected ewes and find the correlation coefficients among all parameters.

\section{MATERIALS and METHODS}

\section{1- Animals:}

The present study was carried out at the Faculty of Veterinary Medicine, Duhok University in Duhok, Kurdistan region-Iraq. A total of 120 blood serum samples were collected randomly from different ages and flocks of non vaccinated local ewes within one month after abortion in Duhok governorate of Iraq from February to May 2013. Blood samples were kept and transported in a polyethylene cool box to the laboratory.

\section{2- Blood samples:}

Blood samples of the tested animals were collected aseptically. Serum of the collected samples were separated and kept in a screw capped plastic vials and stored at $-20^{\circ} \mathrm{C}$ until examination. 


\section{3- Serological test (ELISA):}

The brucella I-ELISA antibody test (B. melitensis antigen) kit, along with the user manual was obtained from Svanova Biotech AB, Sweden. The test was performed based on the protocol outlined in the user manual. The samples were found negative results for I-ELISA are considered as a control group. All optical density (OD) values for the test samples as well as the negative control related to the OD value of the positive control are calculated, a positivity values (PP) value equal or more than 15 was taken as positive.

\section{4- Lipids profiles analysis:}

Serum concentration of total cholesterol, triglycerides, high density lipoprotein, were measured enzymatically with a commercial kit (Biolabostandard kits, France). While low density lipoprotein and (LDL) and very low density lipoprotein (VLDL) were measured according to formula that used by Burtis and Ashwood, (1999):
LDL Cholesterol $=$ Total Cholesterol - HDL - $(\mathrm{TG} /$ 5)

VLDL were measured according to VLDL $=\mathrm{TG} / 5$

\section{5- Statistical analysis:}

All data were analyzed by-one-way analysis of variance, the specific group differences were determined by $\mathrm{T}$ test (Bowers, 2008) and the correlation coefficients by using SAS 2001. The accepted level of significant was $\mathrm{P}<0.05$.

\section{RESULTS}

A total of 120 sera from ewes were processed for antibody detection, 47(39.1\%) samples by I-ELISA were founds positive for B.melitensis antibodies. While, 73 samples were found negative results for IELISA.

Brucella infection caused significant increase in mean values of TC, TG, HDL, LDL, and VLDL when compared with control group. (Table 1 and Figure 1).

Table 1: Effect of B.melitensis on serum lipid profiles in ewes.

\begin{tabular}{ccc}
\hline Parameters & Control group $(\mathbf{n = 7 3})$ & Infected group $(\mathbf{n = 4 7})$ \\
\hline TC $\mathbf{~ m g / d l}$ & $90.3 \pm 11.24 \quad \mathbf{b}$ & $143.73 \pm 8.29 \mathbf{a}$ \\
\hline TG $\mathbf{~ m g / d l}$ & $77.00 \pm 13.39 \mathbf{b}$ & $111.60 \pm 13.39 \mathbf{a}$ \\
\hline HDL $\mathbf{~ m g / d l}$ & $19.67 \pm 3.27 \quad \mathbf{b}$ & $46.42 \pm 19.82 \mathbf{a}$ \\
\hline LDL $\mathbf{~ m g / d l}$ & $53.22 \pm 1.62 \quad \mathbf{b}$ & $75.08 \pm 19.20 \mathbf{a}$ \\
\hline VLDL $\mathbf{~ m g / d l}$ & $15.42 \pm 1.31 \mathbf{a}$ & $22.29 \pm 4.22 \mathbf{b}$ \\
\hline
\end{tabular}

*a,b Values carrying the different letters are significantly different at $\mathrm{P} \leq 0.05$.

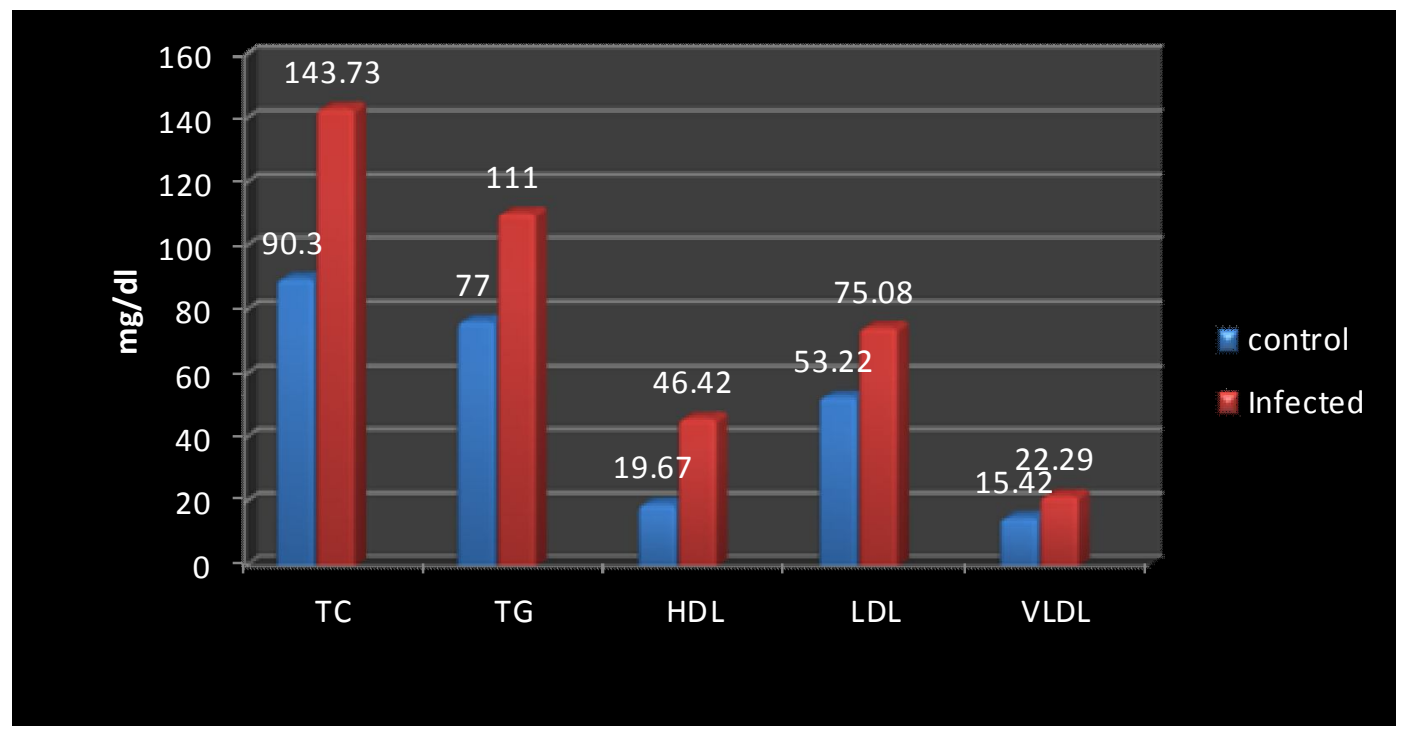

Figure (1): Effect of B.melitensis on serum lipid profiles in ewes

Results also showed significant correlation coefficient among all parameters, the results were seen in Table (2). 
Table 2: Correlation coefficients among parameters.

\begin{tabular}{cccccc}
\hline Parameters & TC & TG & HDL & LDL & VLDL \\
\hline TC $\mathbf{~ m g / d l}$ & $0.94^{* *}$ & & & & \\
\hline TG $\mathbf{~ m g / d l}$ & $0.81^{* *}$ & $0.74^{* *}$ & & & \\
\hline HDL $\mathbf{~ m g / d l}$ & $0.62^{* *}$ & $0.57^{* *}$ & $0.52^{* *}$ & & \\
\hline LDL $\mathbf{~ m g / d l}$ & $0.64^{* *}$ & $0.57^{* *}$ & $0.63^{* *}$ & $0.53^{* *}$ & \\
\hline VLDL $\mathbf{~ m g / d l}$ & $0.69^{* *}$ & $0.61^{* *}$ & $0.59^{* *}$ & $0.45^{*}$ & $0.49^{* *}$ \\
\hline
\end{tabular}

* Significant differences correlation at $\mathrm{P} \leq 0.05 \quad * *$ Highly significant correlation at $\mathrm{P} \leq 0.01$

\section{DISCUSSION}

Results from our study indicate that 47(39.1\%) samples by I-ELISA were founds positive for B.melitensis antibodies. While, in northern Iraq and Mosul province using ELISA, a comparative lower values seroprevalence of $23.6 \%$ in sheep were reported by Arslan et al. (2011). The lower values of $5.2 \%$ in sheep were also observed by Montasser et al. (2011). The high incidence may be due to many factors including the lack of an integrated program to control the disease, the absence of healthy ways to get rid of aborted fetuses and other pollutants, poor nutrition and the methods of management (Kabagambe et al., 2001) as well as the role of wildlife animals, which act as reservoir and spread the disease (Godfroid, 2002).

Our study showed that B.melitensis increased serum levels of lipids profiles in infected ewes and this result agreed with that of Arslan et al. (2011) who indicated that brucellosis increase in serum total cholesterol, LDL-cholesterol and high level of LDL/HDL ratio in infected animals. Significant increased in total lipids compared to control group could be ascribed to the higher levels of free fatty acids (FFA) in infected ewes, caused by increased level of cortisol due to stress of abortion which induced by brucella infection, as well as increased sensitivity of ewes to epinephrine hormone, which leads to the increase in serum FFA concentrations (Piccione et al., 2009). The triglycerides are increased may be due to presence of brucella endotoxins which are causes bacteremia and septicemia (Arslan et al., 2011) or due to loss of proteins because of glomerulonephritis and nephrotic syndrome resulting from brucellosis (Stockham and Scott, 2003). These variation were related to the physiological adaptations of sheep for their energy needs during pregnancy and abortion (Nazifi et al., 2002) and also the age of the infected animals effect on the serum lipids profiles levels (Gagan, 2014). Nevertheless, it could be noted that brucella infection causes arise in serum levels of TC, TG, HDL and LDL.

\section{REFERENCES}

Amal, H.A. (2009): The effect of brucellosis on lipid Profile and oxidant-antioxidants status. Iraqi J. Pharm. Sci., 18, pp 26-31.

Arslan, S.H.; Hassan, M.M.; Mohammad, B.A.; AlHussary, N.A. and Al-Obaidi, Q.T. (2011): Changes in some biochemical parameters accompanied with brucellosis in sheep. Iraqi J. Vet. Sci. 25(2): 107-110.

Bowers, D. (2008): Medical statistics from scratch. $2^{\text {nd }}$ ed. Edited by Wiley, J. and sons Ltd. Southern gate, UK. pp 187-201.

Gagan, S.L. (2014): How to interpret the results of a lipid panel. Demand Media Inc. USA. pp 56-87.

Godfroid, J. (2002): Brucellosis in wildlife. J. Rev. Sci. Tech. 21: 277-286.

Kabagambe, E.K.; Elzer, P.H.; Geaghan, J.P.; Opuda, A.J.; Scholl, D.T. and Miller, J.E. (2001): Risk factor for brucella seropositivity in goat herd in eastern and western Uganda. J. Pre. Vet. Med. 52: 91-108.

Montasser, A.M.; Affi, M.M.; El-Bayoumy, E.M.; Abdul-Raouf, U.M and Mohamad, H.A. (2011): Efficiency of serological tests for detection of brucellosis in ruminant at south provinces of Egypt. Global Vet. 6(2): 156-161.

Marcos, E.; Mazur, A.; Cardot, P. and Rayssiguire, $Y$. (1990): The effect of pregnancy and lactation on serum lipid and lipoprotein levels in dairy cows. J. Anim. Physiol. Anim. Nutr. 64, 133-138.

Nazifi, S.; Saeb, M. and Ghavami, S.M. (2002): Serum lipid profile in Iranian fat trailed sheep in late pregnancy period. J. Vet. Med. 49, 9-12.

Piccione, G.; Caola, G. and Giannetto, C. (2009): Selected biochemical serum parameters in ewes during pregnancy, post-parturition, lactation and dry period. Animal Science Papers and Reports. 27: (4) pp 321-330.

Stockham, S.L. and Scott, M.A. (2002): Fundamental of veterinary clinical pathology. Iowa state press, USA. pp 251-277.

Young, E.J. (1995): An overview of human brucellosis. J. Clin. Infect. Dis. 21: 283-289. 


\section{تأثير داء البروسيلا على دهون مصل الدم في النعاج \\ أصبل أنور النقشبندي ، أفين أكرم إبراهيم ، عمر حسن عزيز}

Email: asselvet2000@yahoo.com

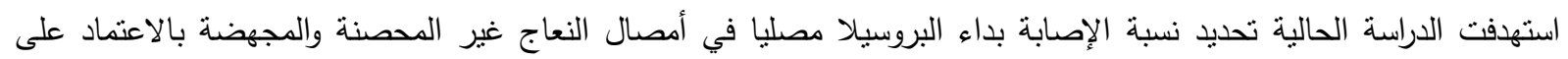

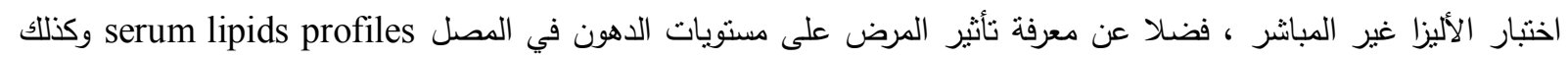

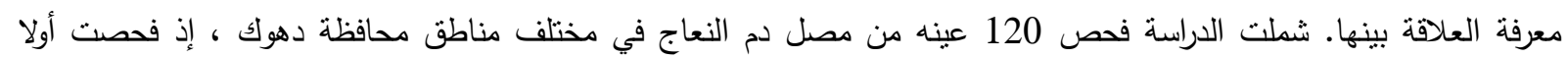

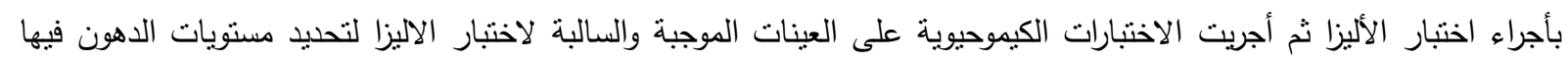

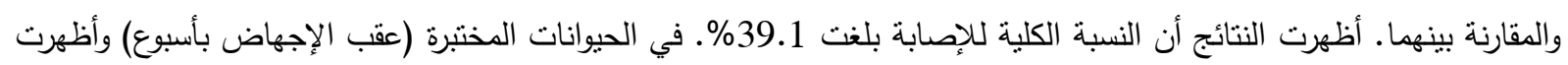

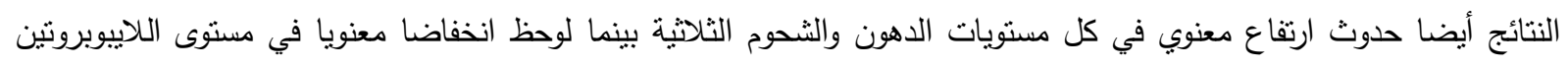

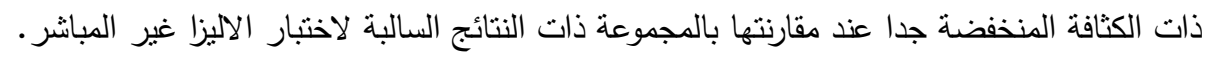

